\title{
Dragkamp og balansegang. Frigjøringsmarkeringene i Kirkenes 1954-1994: Et minnepolitisk perspektiv
}

\author{
Kari Aga Myklebost* \\ UiT Norges arktiske universitet, Norge
}

\author{
Joakim Aalmen Markussen \\ Narviksenteret, Norge
}

\begin{abstract}
Commemorating the Red Army Liberation in Kirkenes, Norway, 1954-1994 This study traces the development over fifty years of the joint Norwegian-Soviet/Russian commemorations of the Red Army liberation of the eastern part of Finnmark County, Norway, in October 1944. The first commemorative events were held in October 1954 in the town of Kirkenes close to the Norwegian-Soviet border. Throughout the Cold War and into the post-Soviet period, such events have been arranged in Kirkenes every five years, with representatives of the Norwegian state authorities acting as hosts to a Soviet/ Russian delegation. The focal point of these events has been a ceremony held by the Liberation Monument, unveiled in 1952 to honour the Red Army soldiers who liberated Norwegian territory by driving back the Nazi occupation forces. This article documents how the tradition of joint commemorations developed across the Iron Curtain divide as part of a predominantly diplomatic struggle over the events of October 1944, between Norway, a small state and NATO-member, and the superpower that was the Soviet Union. Our study concludes that, despite the struggle, which stemmed from Cold War tensions and competing security perceptions and interests, these joint commemorations have served as a stabilizing element in bilateral relations, producing a narrative not only about the Red Army liberation of eastern Finnmark, but also of friendship and mutual respect between the peoples of Norway and Russia, and of a long tradition of peaceful relations between the two states.
\end{abstract}

Keywords: Second World War, Red Army, liberation, memory politics, Norway, Soviet Union, Russia

\footnotetext{
^Kontaktinformasjon: Kari Aga Myklebost, e-post: kari.myklebost@uit.no 
Studier av minnepolitikk framhever ofte det dynamiske og omskiftelige; at minner er gjenstand for konstant forhandling og at de stadig tolkes på nytt i lys av samtidas endrede politiske prioriteringer. I denne artikkelen tar vi for oss de felles norsksovjetiske, og etter 1991 norsk-russiske, minnemarkeringene ved Frigjøringsmonumentet i Kirkenes i Øst-Finnmark. ${ }^{1}$ Frigjøringsmarkeringene i Kirkenes har ved første øyekast hatt en slående kontinuitet gjennom den kalde krigen og inn i den postsovjetiske perioden. Markeringene ble initiert i 1954 og har siden den gang blitt gjennomført i femårssykluser, med norske myndigheter som vertskap og sovjetiske/ russiske delegasjoner som inviterte gjester. Høytstående militære og politiske aktører fra begge sider har deltatt. Et nærmere studium viser imidlertid at de jevnlige markeringene har vært gjenstand for en betydelig dragkamp mellom norske og sovjetiske aktører. Vi vil i denne artikkelen følge markeringenes utvikling fra 1954 og fram til 50-årsjubileet i 1994, med fokus på hvordan de ble etablert, hvilke dragkamper som utspilte seg og hvordan markeringene gradvis fikk en fast form gjennom samhandling mellom norske og sovjetiske aktører. ${ }^{2}$ Hvem var initiativtakere og deltakere, og hva var innholdet i markeringene? Hvilke symbolske handlinger og hvilken retorikk ble tatt i bruk under seremoniene? Rammen for den empiriske kartleggingen er den kald krigs-politiske konteksten som markeringene inngikk i og den endrede politiske situasjonen etter Sovjetunionens fall.

Vi starter artikkelen med å giøre rede for noen sentrale analytiske begrep og perspektiver, samt kildematerialet og dets styrker og begrensninger. Artikkelens hoveddel kartlegger markeringene fra 1954 til 1994, med særlig vekt på de første markeringene på 1950- og 1960-tallet. Som vi skal se, ble det da lagt noen grunnrammer for hvordan markeringene skulle gjennomføres som det norske vertskapet valgte å holde fast ved gjennom resten av sovjetperioden. Ved 50-årsmarkeringen i 1994 ble grunnrammene utvidet fra norsk side - uten at dette endret på retorikken i taler. Markeringen i 1994 representerte slik både et brudd og en kontinuitet i forhold til tradisjonen som var nedfelt giennom den kalde krigen. Vi avslutter artikkelen med en drøfting av markeringenes minnepolitiske funksjon over tid: Hvilket narrativ kan vi lese ut av de symbolske handlingene og retorikken som har blitt framført i Kirkenes, og hvordan kan man best forklare den langvarige tradisjonen med felles markeringer? Vi vil argumentere for at svaret på det siste spørsmålet ligger i at minnemarkeringene, til tross for dragkamp og balansegang, har fungert som et stabiliserende element i de bilaterale relasjonene mellom de to nabostatene.

\footnotetext{
${ }^{1} \mathrm{Om}$ oppføringen av monumentet $\mathrm{i}$ samarbeid mellom norske og sovjetiske myndigheter, se Joakim Aa. Markussen, «Sikkerhetspolitisk minnediplomati: Opprettelsen av Frigjøringsmonumentet i Kirkenes 1945-1952", artikkel under fagfellevurdering.

${ }^{2}$ Frigjøringsmarkeringene har siden 1994 utviklet seg og særlig fått en sterkere regionalpolitisk dimensjon innenfor rammene av Barentssamarbeidet. Dette lar vi her ligge av plassmessige hensyn.
} 


\section{Minnemarkeringer som samhandling mellom norske og sovjetiske aktører}

Historiske jubileer og markeringer kan forstås på ulike måter; de kan leses som speil for samfunnet, som refleksjoner av holdninger og normer, eller de kan forstås som utøvelse av politikk. Vi har valgt det siste perspektivet, og konsentrerer oss om frigjøringsmarkeringene i Kirkenes som minnepolitikk. Minnepolitikk kan defineres som bruk av hendelser fra fortida til å fremme politiske interesser og verdier i samtida, altså at fortida tas i bruk som en symbolsk kraft i politikken (Eriksen, 1999; Wijermars, 2019). Minnesmerker og grunnfortellinger som etableres gjennom seremonier forteller noe om hvordan aktørene bak markeringene ønsker å minnes fortida innenfor rammene av den samtida de står $\mathrm{i}$.

For bedre å gripe minnemarkeringers betydning, kan man skille mellom tre ulike aspekter ved dem: intensjon, produksjon og resepsjon (Aagedal et al., 2017). Intensjon handler om hva organisatorene ønsker å oppnå med en markering og hvilke motiv som ligger bak. Produksjon tar for seg hvordan en markering arrangeres og hvilke meningsbærende narrativ som etableres gjennom taler og symbolske handlinger. Resepsjon handler om hvordan et arrangement blir mottatt, om deltakelse og opplevelse - og om danning av minnefellesskap og hva slags identitetspolitikk en markering fremmer (Eriksen, 1999).

Avisoppslag om frigjøringsmarkeringene i norsk og sovjetisk presse og arkivmateriale fra det norske utenriksdepartementet er våre hovedkilder. ${ }^{3}$ Avisoppslagene brukes til å kartlegge markeringenes faktiske og symbolske innhold, deres utvikling og den bredere politiske sammenhengen de ble satt inn i. ${ }^{4}$ Arkivmaterialet fra det norske utenriksdepartementet brukes til å belyse norske og sovjetiske aktørers intensjoner og ønsker for markeringene. Vi har ikke kunnet gjennomføre arkivarbeid i Russland i forbindelse med artikkelen, men materialet fra Utenriksdepartementet forteller om sovjetiske initiativ og ønsker knyttet til minnemarkeringene som vi har kunnet nyttiggjøre oss i analysen. Det er allikevel primært norske myndigheters politiske avveininger som belyses i artikkelen. En mer dyptgående forståelse av minnekultur knyttet til frigjøringen kunne man få ved å foreta intervjuer med deltakere på markeringene, samt ved å gå systematisk gjennom de mange memoarene og dokumentariske bokutgivelsene som har blitt publisert om frigjøringen av tidsvitner, veteraner og journalister. ${ }^{5}$ Vår analyse er altså ikke uttømmende, men kan leses som en kartlegging av markeringene gjennom femti år med fokus på samhandling mellom

\footnotetext{
${ }^{3}$ Alle oversettelser til norsk fra sovjetiske presseklipp er gjort av Kari Aga Myklebost.

${ }^{4}$ Avismaterialet er hentet fram gjennom søk i presse-databasene Eastview, Atekst og den digitaliserte avissamlingen hos Nasjonalbiblioteket i Oslo, med søkestrengene "Kirkenes AND frigjøring», «Освобождение AND Киркенес AND памятник», «Петсамо-Киркенесская операция AND памятник» og bruk av ulik trunkering og tidsavgrensning. Dette ga i all hovedsak treff i hovedstadspresse.

${ }^{5}$ Se f.eks. Gamnes, 2014; Gorter et al., 2005; Lippe, 1964.
} 
norske og sovjetiske aktører, hvordan markeringene har blitt arrangert og hvilket meningsbærende narrativ markeringene har frambrakt over tid.

Både i Norge og Sovjetunionen hadde minnet om krigen en sentral plass i offentligheten gjennom etterkrigstida, som et samlende referansepunkt for befolkningen i de to landene (Eriksen, 1995; Markwick, 2012; Narinskiy, 2015). Frigjøringsmarkeringene i Kirkenes kan imidlertid ikke forstås innenfor en rent nasjonal ramme; de ble utviklet i samspill mellom Norge og Sovjetunionen, og fra norsk side har man markert tapet ikke av egne, men av nabostatens soldater på norsk jord (Markussen, 2020). Både produksjonen av markeringene og det historiske referansepunktet som de viser til - frigiøringen - har slik hatt en grunnleggende bilateral dimensjon for aktørene i de to nabostatene. Relasjonene mellom Norge og Sovjetunionen/Russland har blitt utforsket i flere verk og dokumentsamlinger gjennom de siste tiårene. ${ }^{6}$ I tobindsverket om forholdet mellom Norge og Russland 1814-2014 finner vi grundige beskrivelser både av det man ofte kaller for realhistoriske forhold og av kulturelle faktorer som har formet de bilaterale relasjonene, som gjensidige forestillinger om hverandre som nabostater og folk (Holtsmark, 2015a; Nielsen, 2014).

Ved å se nærmere på frigjøringsmarkeringene gjennom femti år søker vi å utvide forståelsen av hvordan symbolske handlinger og retorikk har fungert som del av en særegen naboskapspolitikk som norske og sovjetiske/russiske aktører har utviklet over tid. Utgangspunktet for en slik analyse er at kulturelle symboler og retorikk har en virkningsdimensjon; gjennom å forme våre tankesett, virker de også inn på våre handlingsmønstre, uavhengig av om symbolene avspeiler en bakenforliggende realitet eller ikke. Et eksempel på dette finner vi i den seiglivede norske forestillingen om «den russiske fare». Historikere som har undersøkt emnet, har ikke funnet empiriske belegg for at Tsar-Russland hadde ekspansjonistiske planer overfor Norge, men forestillingen om en slik trussel fikk allikevel betydelig gjennomslag i ledende norske politiske og militære kretser på 1800-tallet (Nielsen, 2001).

De norsk-sovjetiske relasjonene endret seg dramatisk gjennom krigen og de første etterkrigsårene. Fra sommeren 1941 sloss sovjetiske soldater på alliert side, etter det tyske angrepet på Sovjetunionen gjennom Operasjon Barbarossa. De sovjetiske soldatene som krysset grensen til Norge i oktober 1944 kom derfor som allierte, og ble hyllet som frigiørere i pressen og av sentrale aktører som Kong Haakon og statsminister Einar Gerhardsen. Bak denne takknemligheten lå samtidig en usikkerhet fra norske myndigheters side om de egentlige intensjonene til Sovjetunionen. Den norske småstaten, som tradisjonelt hadde hatt sterke økonomiske og politiske bånd til vestmaktene, fryktet at den kommunistiske stormaktnaboen skulle ta seg til rette

\footnotetext{
${ }^{6}$ Noen hovedarbeider er Bones \& Mankova, 2010; Büchten et al., 2004; Egge et al., 2015; Fagertun, 2015; Holtsmark, 1995, 2015a; Holtsmark et al., 2020; Jackson \& Nielsen, 2005; Kan, 1988; Myklebost \& Bones, 2012; Myklebost et al., 2020; Nielsen, 2014; Rotihaug, 2000.
} 
på norsk jord (Holtsmark, 2015b). Ideer om sovjetisk ekspansjonisme ble propagandert av Tyskland, og var utbredt i enkelte kretser i Sverige (Bones, 2015). I Norge ble dette tilbakevist i løpet av 1945, da de sovjetiske soldatene trakk seg ut fra norsk territorium.

For Sovjetunionen framsto Norge fra 1944 som et lite, men betydningsfullt naboland, først og fremst i kraft av at man nå delte grense igjen (Komarov, 2015). Derfor gikk sovjetiske representanter i 1944-45 aktivt inn for å befeste forståelsen av Den røde armé som frigjørere i Øst-Finnmark og motvirke ideer om sovjetiske ekspansjonistiske planer i Norge (Bones, 2015). I kjølvannet av frigjøringen valgte Norge å føre en brobyggingspolitikk som hadde som mål å bringe Sovjetunionen nærmere de vestlige statene. Dette viste seg å være en vanskelig linje, og fra 1948 knyttet Norge seg nærmere til vestmaktene igjen. Da Norge i 1949 sluttet seg til Atlanterhavspakten, endret rammene for norsk-sovjetiske relasjoner seg grunnleggende. De to nabostatene sto nå på hver sin side i de politiske spenningene mellom øst og vest som utviklet seg til den kalde krigen. Tida fram til 1953 har blitt betegnet som «de dype kald krigs-årene», med harde fronter mellom øst og vest (Holtsmark, 2015a, s. 347).

\section{4: En minnemarkering blir til}

Sommeren 1954 mottok Utenriksdepartementet et brev fra Norsk-sovjetrussisk samband. Sambandet forespurte «om det fra offisielt norsk hold vil bli gjort noe for å feire minnet om frigjøringen av Finnmark». ${ }^{7}$ To år tidligere var Frigjøringsmonumentet i Kirkenes avduket, og høsten 1954 ville det være ti år siden de sovjetiske troppene befridde Øst-Finnmark fra de tyske okkupasjonsstyrkene. Etter sambandets syn var «[d]enne betydningsfulle begivenhet [...] ennå levende i de fleste norske sinn, særlig naturligvis i Nord-Norge, og Norsk-sovjetrussisk samband anser det derfor for å være en av dets viktigste oppgaver i år å bidra til at minnet blir feiret på en verdig måte». ${ }^{8}$ Det var ikke oppsiktsvekkende at sambandet tok initiativ til en slik markering. De første delene av organisasjonen hadde blitt etablert i mars 1945 av daværende fylkesmann i Finnmark Peder Holt og den sovjetiske kommandanten i Kirkenes (Bones, 2015). Ifølge formålsparagrafen skulle organisasjonen arbeide for «å styrke vennskapet og utvikle det sosiale, økonomiske og kulturelle sambandet mellom Norge og Sovjetunionen» (Rotihaug, 2000, s. 28). I de umiddelbare etterkrigsårene var det mange i Norge som sympatiserte med dette, blant andre utenriksminister Trygve Lie, som holdt tale under sambandets festmøte høsten 1945 (Bones, 2015). Etter som den kalde krigen tilspisset seg, ble imidlertid både Arbeiderpartiet og konservative norske politikere kritisk innstilt. Sambandet ble i økende grad oppfattet som en kommunistisk dekkorganisasjon som fremmet sovjetiske interesser i

\footnotetext{
${ }^{7}$ Norsk-sovjetrussisk samband til UD, 13.7.1954, RA/S-2259/Dz/L0484/Doss 8.6.15B, Bd. I.

${ }^{8}$ Norsk-sovjetrussisk samband til UD, 13.7.1954, RA/S-2259/Dz/L0484/Doss 8.6.15B, Bd. I.
} 
Norge, blant annet fordi det ble ledet av medlemmer fra Norges Kommunistiske Parti (NKP) i samarbeid med sovjetiske kontaktpersoner (Rotihaug, 2000, s. 7).

Sambandets forespørsel i 1954 kan ses i sammenheng med tøværet under Sovjetunionens nye statsoverhode Nikita Khrusjtsjov, som etter Stalins død året før hadde lansert en linje om fredelig sameksistens mellom øst- og vestblokken. Det er nærliggende å anta at Norsk-sovjetrussisk sambands initiativ var motivert av at man mente at det nå var mulig å få til en minnemarkering. Brevet fra sambandet ble også sendt til formannskapet i Sør-Varanger, men kommunen erklærte at "et eventuelt arrangement bør legges opp av Statens organer». ${ }^{9}$ Omtrent samtidig fikk fylkesmann i Finnmark Anders Aune en invitasjon til Murmansk for en delegasjon på ti stykker i midten av oktober for å markere at det var gått ti år siden starten på den sovjetiske operasjonen som førte til frigjøringen av Øst-Finnmark (Aune, 1996, s. 137). Aune takket ja i samråd med Utenriksdepartementet, og i august 1954 bestemte den norske regjeringen at det skulle arrangeres «en høytidelighet i Kirkenes den 24. oktober 1954 til minne om frigjøringen av Finnmark for 10 år siden». En invitasjon gikk ut til den sovjetiske ambassadøren Georgij P. Arkadjev, som tok velvillig imot og betegnet arrangementet som et "positivt initiativ». ${ }^{10}$

Avisa Friheten, organet til NKP, publiserte noen dager senere en pressemelding fra den sovjetiske ambassaden i Norge, om at Vladimir Sjtsjerbakov, omtalt som "øverstkommanderende for sovjettroppene som befridde Norge», skulle delta i den sovjetiske delegasjonen. ${ }^{11}$ UD kommenterte oppslaget i sin interne korrespondanse, og skrev at Friheten

i sin nidkjærhet har forbedret ambassadens melding, idet avisen uttaler at delegasionen bl.a. kom til å omfatte [...] Sjerbakov «øverstkommanderende for sovjettroppene som befridde Norge». Ambassaden [den sovjetiske] gikk ikke lenger enn til å omtale generalen som øverstkommanderende for de tropper som befridde NordNorge. I Utenriksdepartementets kommuniké er general Sjerbakov betegnet som øverstkommanderende sovjettropper som rykket inn i Finnmark. ${ }^{12}$

Den første dragkampen om hvordan hendelsene i oktober 1944 skulle markeres, var i gang. Selv om det ikke er grunnlag for å tro at UD var motvillig innstilt til en felles tiårsmarkering, var norske myndigheter tydelig opptatt av begrepsbruken knyttet til den sovjetiske militære operasjonen på norsk jord. Man var fra norsk side også opptatt av at Sovjetunionen ikke ble framstilt som eneste aktør under den siste krigsvinteren i Finnmark. Peder Holt, fylkesmann i Finnmark vinteren 1944-45 og nå fiskeriminister, skrev en lang artikkel til norsk presse om den siste krigsvinteren.

\footnotetext{
${ }^{9}$ Sør-Varanger kommune til UD, 6.8.1954, RA/S-2259/Dz/L0484/Doss 8.6.15B, Bd. I.

${ }^{10}$ Aide-Memoire 26.8.1954, RA/S-2259/Dz/L0484/Doss 8.6.15B, Bd. I; Notat, 26.8.1954, RA/ S-2259/Dz/L0484/Doss 8.6.15B, Bd. I.

${ }^{11}$ "Ø.K for sovjettroppene som befridde Nord-Norge», Friheten, 13.9.1954, RA/S-2259/Dz/L0484/ Doss 8.6.15B, Bd. I. Artikkelforfatternes kursivering. Sjtsjerbakov var i realiteten sjef for 14. armé. Øverste ansvar for troppene lå hos Meretskov, sjef for Karelske Front.

${ }^{12}$ Notat, 13.9.1954, RA/S-2259/Dz/L0484/Doss 8.6.15B, Bd. I. Artikkelforfatternes kursivering
} 
Artikkelen ble publisert i flere norske aviser etter at den først hadde vært sendt til Utenriksdepartementet for gjennomlesing. Holt skrev utfyllende om arbeidet med å opprette siviladministrasjonen etter frigjøringen, og hans artikkel dreide seg hovedsakelig om gjenopprettelsen av norsk siviladministrasion i tiden etter den sovjetiske innmarsjen i Finnmark. På den måten understreket han at også Norge hadde gjort en avgjørende innsats i Finnmark. ${ }^{13}$

Selve markeringen i Kirkenes i slutten av oktober 1954 foregikk i konfliktfrie former. Det norske vertskapet besto av justisminister Gustav Sjaastad og en håndfull norske høytstående offiserer. Fylkesmann i Finnmark Anders Aune, borgermester i Kirkenes Hilmar Isaksen og den norske grensekommisæren samt representanter for Kirkenes-samfunnet deltok også. Høydepunktet under markeringen var kransenedlegging ved Frigjøringsmonumentet, hvor mellom ett og to tusen mennesker hadde møtt opp (Aftenposten, 1954d). Etter markeringen i Kirkenes besøkte den sovjetiske delegasjonen og det norske vertskapet steder der det hadde foregått kamper, som Skafferhullet ved den norsk-sovjetiske grensen. Delegasjonen besøkte også AS Sydvarangers gruveanlegg, deltok på en festgudstjeneste, fikk omvisning i den gjenreiste byen og snakket med lokale familier (Izvestija, 1954a, 1954b). Det hele foregikk over to dager, med en festmiddag for de offisielle representantene i regi av det norske vertskapet og en mottakelse holdt av den sovjetiske ambassadøren hvor hele befolkningen i Kirkenes var invitert. (Aftenposten, 1954b; Verdens Gang, 1954).

Selv om markeringen foregikk i en atmosfære preget av tøværspolitikken, vitner sammensetningen av det norske vertskapet om den sikkerhetspolitiske spagaten som Norge sto i som Nato-medlem med behov for å ivareta gode relasjoner med Sovjetunionen. Opprinnelig skulle forsvarsminister Kai Knudsen representere regjeringen i Kirkenes - men han ble opptatt med et Nato-møte i Paris på selve minnedagen 24. oktober. Dermed ble det justisminister Sjaastad som ledet det norske vertskapet. Som et plaster på såret hadde den sovjetiske delegasjonen fått møte den norske forsvarsministeren i Oslo noen dager tidligere, sammen med kronprins Olav og statsminister Oscar Torp (Aftenposten, 1954b, 1954c). Den sovjetiske delegasjonen tilbrakte til sammen rundt 12 dager i Norge (Aftenposten, 1954a, 1954b, 1954e, 1954f). Dette skulle for øvrig bli første og siste gang under den kalde krigen at Norge var representert med en statsråd under minnemarkeringene i Kirkenes.

I sovjetisk presse ble markeringen i 1954 framstilt som svært vellykket. 25. oktober trykket Pravda en artikkel under overskriften «Det norske folk markerer tiårsjubileet for Den sovjetiske hærs frigjøring av Nord-Norge». Avisa kunne fortelle at Kirkenes by og skipene på havna var pyntet med sovjetiske og norske flagg, og at det var feststemning i gatene (Pravda, 1954). Izvestija understreket at den sovjetiske delegasjonen besto av høyt rangerte veteraner som generalløytnant V.I. Sjtsjerbakov, som hadde ledet de sovjetiske landstyrkene i 1944, og S.D. Zjurin, som hadde ledet

${ }^{13}$ Notat, 14.10 .1954$, RA/S-2259/Dz/L0484/Doss 8.6.15B, Bd. I. 
deler av Nordflåten under kampene (Izvestija, 1954). De tyske soldatene ble omtalt i fordømmende og sterkt ideologiserte termer, som «de forbryterske hitleristene». Talen fra ambassadør Arkadjev understreket på samme måte som pressemeldingen $\mathrm{i}$ Friheten at Den røde armé kom til Norge som befriere:

I 1944 feide sovjettropper fra den karelske front Nord-Norge ren for okkupanter. Sovjetarmeen rykket inn på Norges territorium som en frigjøringsarme og da den hadde utført den oppgave som var pålagt den, nemlig å tilintetgiøre hitlerarmeene i NordNorge, trakk den seg øyeblikkelig ut av norsk område. [...] Måtte vårt møte idag, viet 10 års dagen for Nord-Norges frigjøring av Sovjetarmeen, som er vennligsinnet overfor Norges folk, bidra til å opprettholde freden, styrke og utvikle de gode naboforhold mellom Sovjet-Unionen og Norge. ${ }^{14}$

Pravda refererte fra justisminister Sjaastad sin tale, og framhevet hvordan han hadde takket de sovjetiske soldatene og avsluttet talen med følgende formulering: «Historien kjenner ikke til militære sammenstøt mellom Norge og Sovjetunionen. Vi håper av fullt hjerte å kunne leve i godt naboskap også i framtiden, i samforståelse og fred. I takknemlig minne om bidraget til de sovjetiske styrkene her i nord og $\mathrm{i}$ håp om fortsettelse av våre gode naborelasjoner, legger jeg ned denne kransen på vegne av den norske regjeringen» (Pravda, 1954). Også avisa Nordlys refererte fra Sjaastad sin tale. Her framkom imidlertid et litt annet bilde; etter de rosende formuleringene om Den røde armés kampvilje, disiplin og mot, poengterte Sjaastad at frigjøringen ikke utelukkende var et resultat av de sovjetiske styrkenes innsats, men at norske avdelinger også hadde deltatt: "Lenge hadde sovjetiske og norske styrker kjempet for den samme sak: Nå kjempet de også på samme front». ${ }^{15}$ Ifølge avisa Nordlys hadde Sjaastad understreket hvordan norske tropper supplerte innsatsen til Den røde armé og fullførte frigjøringen ved at de «trengte videre vestover og brakte resten av Finnmark under norsk kontroll» (Nordlys, 1954).

Til tross for den noe ulike vektleggingen av hendelsene i oktober 1944, konkluderte den sovjetiske delegasjonen med at minnemarkeringen hadde vært svært vellykket. ${ }^{16}$ Gjennom rapporter fra den norske ambassaden i Moskva fikk UD forsterket dette inntrykket. Krasnaja Zvezda, det sovjetiske forsvarsministeriets organ, skrev at de «sovjetiske troppers uselviske hjelp til den stedlige befolkning utløste en varm takknemlighet hos Nord-Norges befolkning og hele det norske folk». ${ }^{17}$ Avisa kunne også fortelle at den norske regjeringen i 1944 hadde meddelt at «Befrielsen av Nord-Norge vil bli hilst med glede og entusiasme av hele det norske folk, og den

\footnotetext{
${ }^{14}$ Notat, 19.10.1954, RA/S-2259/Dz/L0484/Doss 8.6.15B, Bd. I. Den Karelske Front var en avdeling, og navnet ble vanligvis skrevet med store forbokstaver. I originaldokumentet i UDs arkiver som dette sitatet er hentet fra, er navnet skrevet med små bokstaver.

${ }^{15}$ Sjaastads tale, 24.10.1954, RA/S-2259/Dz/L0484/Doss 8.6.15B, Bd. I.

${ }^{16}$ Moskva til UD, 2.11.1954, RA/S-2259/Dz/L0484/Doss 8.6.15B, Bd. I.

${ }^{17}$ Moskva til UD, 26.10.1954, RA/S-2259/Dz/L0484/Doss 8.6.15B, Bd. I.
} 
vil føre til en videre styrkelse av vennskapet mellom våre land». ${ }^{18}$ "Feiringen av den bemerkelsesverdige dato - 10-årsdagen for befrielsen av Nord-Norge av sovjetiske tropper - tjener utvilsomt til å utvikle videre de vennskapelige forbindelser mellom Norge og Sovjet-Samveldet», skrev avisa. ${ }^{19}$

\section{9-1969: Sovjetiske initiativ og norsk tilbakeholdenhet}

Den første markeringen i 1954 skulle komme til å danne utgangspunkt for seinere arrangement $\mathrm{i}$ Kirkenes $\mathrm{i}$ faste femårsintervaller. Samtidig viser arkivmateriale fra det norske utenriksdepartementet at norske myndigheter ble noe overrumplet hver gang det ble aktuelt å avholde en minneseremoni i Kirkenes i de kommende to tiårene. I $1959 \mathrm{kom}$ et forslag om felles norsk-sovjetisk 15-årsmarkering direkte fra den sovjetiske ambassaden i Oslo. Den norske regjeringen drøftet saken, og konkluderte i et skriv til Utenriksdepartementet at «man ikke kunne unnlate å delta i en slik fellesfeiring, men at alle arrangementer i den anledning måtte foregå i mest mulig beskjedne former og avvikles på lokalt plan» ${ }^{20}$ Fylkesmannen i Finnmark ble orientert om at man fra «norsk side har [...] erklært seg villig til å delta i en slik feiring men samtidig understreket at den bør avvikles i noenlunde beskjedne former». ${ }^{21}$ Peder Holt hadde returnert til stillingen som fylkesmann i Finnmark, og ved et møte med UD i september 1959 ble det bestemt at fylkesmannen skulle være vertskap for arrangementet. Det ble også erklært at det «er viktig å unngå at feiringen i Kirkenes får en sterk anti-tysk karakter. I de taler som holdes fra norsk side, bør derfor hovedvekten legges på utbyggingen av samarbeidet i nord i fremtiden, med understrekning av de spesielle norske ønskemål i den forbindelse». ${ }^{22}$

Det ble statssekretær Erik Himle fra Forsvarsdepartementet som ble regjeringens representant. Himle hadde fått instrukser om å framheve det gode naboskapet mellom Norge og Sovjetunionen, og han gjorde det ved å poengtere sovjettroppenes selvoppofrelse:

Den forsiktighet som de sovjetiske tropper framviste, når det gjaldt ikke å støte norske rettigheter og følelser, vakte alminnelig respekt. Selv idag fortelles det til eksempel om hvorledes de russiske tropper den gang for 15 år siden innkvarterte seg ute i sine telt og unnlot å gjøre bruk av de få privathus som ennå sto igjen her. ${ }^{23}$

Det var planlagt at den sovjetiske delegasjonen skulle gjøre en rundreise i Finnmark, og Himle kommenterte at det norske vertskapet gledet seg til å vise delegasjonen

\footnotetext{
${ }^{18}$ Moskva til UD, 26.10.1954, RA/S-2259/Dz/L0484/Doss 8.6.15B, Bd. I. Jf. også Holtsmark (1995, s. 338).

${ }^{19}$ Moskva til UD, 26.10.1954, RA/S-2259/Dz/L0484/Doss 8.6.15B, Bd. I.

${ }^{20}$ Notat, 30.7.1959, RA/S-2259/Dz/L0484/Doss 8.6.15B, Bd. I.

${ }^{21}$ UD til Fylkesmannen i Finnmark, 7.8.1959, RA/S-2259/Dz/L0484/Doss 8.6.15B, Bd. I.

${ }^{22}$ Notat, 4.9.1959, RA/S-2259/Dz/L0484/Doss 8.6.15B, Bd. I.

${ }^{23}$ Utkast til Himles tale, udatert, RA/S-2259/Dz/L0484/Doss 8.6.15B, Bd. II.
} 
«hva vi har bygget opp i løpet av disse 15 årene» (Finnmarken, 1959). Markeringen fikk oppmerksomhet i sovjetiske aviser, og den norske ambassaden i Moskva kommenterte at oppslagene var «fri for polemikk i forbindelse med dagens politiske spørsmål» (Dolmatovskij, 1959; Golosjubov, 1959). ${ }^{24}$ I UDs rapporter fra markeringen sto det at «Feiringen ble ikke utnyttet for politiske formål, utover det at det ble demonstrert fredelig innstilling og godt naboskap. Politiske stridsspørsmål ble ikke tatt opp i noen av de offisielle taler». ${ }^{25}$ I tillegg ble det understreket at talene under markeringen "hadde mindre anti-tysk karakter enn ved tiårsjubileet». ${ }^{26}$ Norske myndigheter synes å ha pustet lettet ut. Kildene viser hvordan man la ned en innsats fra norsk side for å skalere ned og forenkle det sovjetiske forslaget til markering. Man var også på vakt mot at den sovjetiske siden skulle bruke markeringene til å presse den norske småstatsnaboen, særlig når det gjaldt Nato-medlemskap og Norges forhold til Vest-Tyskland. For å hindre dette og samtidig fremme en konstruktiv tone, vektla man fra norsk side godt naboskap og framtidige samarbeidsmuligheter i nord.

Vi kan også se elementene i det som skulle bli et felles narrativ om det norskrussiske forholdet slik det ble formidlet i taler og symbolske handlinger i Kirkenes; det handlet om hvordan Den røde armés soldater kom som frigjørere, som var disiplinerte, hensynsfulle og hjelpsomme. Gjennom ord og kransenedleggelser uttrykte Norge takknemlighet og beundring overfor de sovjetiske soldatene som hadde ofret sine liv, og fra begge sider snakket man om det store vennskapet mellom det norske og sovjetiske folk. Man understreket at Norge og Russland aldri hadde vært i krig, og at det eksisterte et historisk godt og fredelig naboskap århundrer tilbake $\mathrm{i}$ tid, som måtte bevares og utvikles i framtiden. Som vi skal se, ble dette narrativet gjentatt gjennom de påfølgende tiårenes markeringer.

20-årsmarkeringen i 1964 ble igjen utløst av Norsk-sovjetrussisk samband. I et brev til departementet skrev formannen i sambandet, Knut Eidsvold, at «Vi tror det ville være riktig, spesielt sett i sammenheng med den siste tids gunstige utvikling av forbindelsene mellom våre to land om norske myndigheter tok initiativet til en markering av 20-årsdagen for befrielsen av Finnmark». ${ }^{27}$ Eidsvold hadde trolig Nikita Khrusjtsjovs statsbesøk til Norge samme sommer i tankene. Besøket var det siste av en rekke gjensidige regjeringsbes $ø$ f fra 1961, og i kjølvannet av disse hadde flere nye samarbeidsfelt mellom Norge og Sovjetunionen blitt åpnet. Vannkraftutbyggingen ved Boris Gleb i Pasvikelva som nylig var ferdigstilt framsto som et lysende eksempel på hva man kunne få til i fellesskap, og det rådet en optimistisk stemning i det bilaterale forholdet. Samtidig var norske myndigheter på vakt mot sovjetiske utfall mot norsk Nato-medlemskap, og et forslag fra Khrusjtsjov om å bytte ut medlemskapet

\footnotetext{
${ }^{24}$ Moskva til UD, 30.10.1959, RA/S-2259/Dz/L0484/Doss 8.6.15B, Bd. II.

${ }^{25}$ Notat til politisk kontor, 4.11.1959, RA/S-2259/Dz/L0484/Doss 8.6.15B, Bd. II.

${ }^{26}$ Notat til politisk kontor, 4.11.1959, RA/S-2259/Dz/L0484/Doss 8.6.15B, Bd. II.

${ }^{27}$ Sambandet til UD, 20.6.1964, UD/Doss 8.6.15B/III.
} 
med stormaktsgarantert nøytralitet hadde blitt kontant avvist (Holtsmark, 2015a, s. 398-402; Kan, 1988, s. 34-41). I brevet om en 20-årsmarkering ønsket sambandet at regjeringen skulle invitere til et «besøk av sovjetiske marinefartøyer [...] til de viktigste steder i Finnmark» ${ }^{28}$ Helt nederst i brevet stod det at sambandet hadde sendt en kopi av brevet til den sovjetiske ambassaden i Oslo. Ved siden av denne opplysningen hadde noen i UD notert «NB!». ${ }^{29}$

Det finnes ingen dokumenter i UDs arkiv som gir grunn til å tro at Norge allerede hadde planer om å arrangere en markering på dette tidspunktet, men i lys av sambandets initiativ bestemte norske myndigheter at det skulle legges planer for et felles «norsk-sovjetisk arrangement». ${ }^{30} \mathrm{UD}$ ønsket først å gjennomføre en mindre seremoni enn fem år tidligere, men advarte om at det kunne virke "påfallende for russerne» $\mathrm{i}$ og med at det var planlagt å gjennomføre en markering med britisk og fransk deltakelse i Narvik året etter. ${ }^{31}$ Likevel ville UD «i størst mulig utstrekning [...] unngå ekstra foranstaltninger». ${ }^{32}$ Når det gjaldt spørsmålet om et sovjetisk flåtebesøk mente UD at det kunne gi "uheldige spekulasjoner». ${ }^{33}$ Dermed fant UD tilbake til planene for forrige markering. 20-årsdagen for frigjøringen skulle markeres innenfor de samme rammene som fem år tidligere. Bekransning av Frigiøringsmonumentet, middag, invitasjon til den sovjetiske ambassadøren, og som leder for det norske vertskapet en "representant for Regjeringen, f.eks. sjefen for Hæren». ${ }^{34}$

I begynnelsen av august ble den sovjetiske ambassaden orientert om planene. ${ }^{35}$ Etter påtrykk fra sovjetisk hold ble det til slutt enighet om at den sovjetiske marinen skulle gjøre et flåtebesøk som del av frigjøringsmarkeringen, men det skulle skje i Trondheim og ikke i Nord-Norge. ${ }^{36}$ Den sovjetiske siden ytret også ønske om at delegasjonen fikk besøke flere steder i Finnmark i forbindelse med markeringen, og UD anbefalte at ordføreren i Sør-Varanger skulle forsøke å imøtekomme dette. ${ }^{37}$ Samtidig ble det erklært at "for å understreke jubileets lokale karakter anser Utenriksdepartementet det som ønskelig at Fylkesmannen står som innbyder og vert ved middagen i Kirkenes». ${ }^{38}$ Selve markeringen ble avviklet med samme hovedelementer som tidligere, og i taler fra begge sider ble det gitt uttrykk for det gode forhold som hersket mellom de to land, særlig i nord. «Fra sovjetisk side fremkom det ikke noe av

\footnotetext{
${ }^{28}$ Sambandet til UD, 20.6.1964, UD/Doss 8.6.15B/III.

${ }^{29}$ Sambandet til UD, 20.6.1964, UD, Doss 8.6.15B III 1900-1969.

${ }^{30}$ Notat, 27.7.1964, UD/Doss 8.6.15B/III.

${ }^{31}$ Notat, 27.7.1964, UD/Doss 8.6.15B/III.

${ }^{32}$ Notat, 27.7.1964, UD/Doss 8.6.15B/III.

${ }^{33}$ Notat, 27.7.1964, UD/Doss 8.6.15B/III.

${ }^{34}$ Forslag til markering av 20-årsdagen for frigjøringen av Finnmark, 31.7.1964, UD/Doss 8.6.15B/III.

${ }^{35}$ Notat, 3.8.1964, UD/Doss 8.6.15B/III.

${ }^{36}$ UD til Fylkesmannen i Sør-Trøndelag, 5.8.1964, UD/Doss 8.6.15B/III.

${ }^{37}$ UD til Fylkesmannen i Finnmark, 21.8.1964, UD/Doss 8.6.15B/III.

${ }^{38}$ UD til Fylkesmannen i Finnmark, 24.9.1964, UD/Doss 8.6.15B/III.
} 
spesiell interesse", bemerket UD. ${ }^{39}$ Etter markeringen i Kirkenes ble det arrangert en rundreise i Øst-Finnmark med diskusjoner av mulighetene for økt handel og bedre kommunikasjoner på tvers av grensene i nord (Aftenposten, 1964; Verdens Gang, 1964a, 1964b).

Utenriksdepartementet oppsummerte at Sovjetunionen hadde vært tydelig fornøyd med 20-årsmarkeringen, og UD selv mente den hadde vært vellykket. ${ }^{40}$ Pravda og Izvestija trykket referater fra markeringene sammen med personlige erindringer fra høyt rangerte militære veteraner fra Kirkenes, eller journalistiske gjengivelser av dette (Meretskov, 1964; Pravda, 1964; Sjtsjerbakov, 1964; Vavilov, 1964). Her ble det varme vennskapet mellom nabofolkene framhevet i sovjetideologiske termer. Artiklene inneholdt også personlige minner om den menneskelige varmen og takknemligheten som Den røde arme ble møtt med i Norge, samt en rekke detaljer om hvordan de sovjetiske soldatene hjalp den norske sivilbefolkningen. Samtidig benyttet den sovjetiske pressen anledningen til å fremme kritikk av det norske Natomedlemskapet, og hevdet at vestmaktene og særlig USA forsøkte å så ondt blod mellom de to gode naboene ved Ishavet. Konflikt og uvennskap ble påført det norsksovjetiske naboskapet utenfra, var påstanden. Slik kritikk overskygget totalt sett omtalen av frigjøringsmarkeringen i 1964 i sovjetisk presse (Kan, 1988, s. 42).

I august 1968 gikk Sovjetunionen i spissen for Warszawapaktens invasjon av Tsjekkoslovakia for å stoppe den såkalte Praha-våren. Invasjonen ble fordømt av Nato, og den økte spenningen mellom øst- og vestblokken skapte vanskeligheter også for det bilaterale forholdet mellom Norge og Sovjetunionen. Dette kom tydelig til uttrykk i april 1969, da UD nok en gang ble kontaktet av den sovjetiske ambassaden med forespørsel om å arrangere en minnehøytid i Kirkenes i forbindelse med 25-årsdagen for frigiøringen av Finnmark. ${ }^{41}$ Denne gangen framsto departementet som ikke bare uforberedt, men også sterkt ambivalent til en felles markering side om side med sovjetiske representanter. UD kommenterte at det «er neppe til å unngå at 25-årsdagen for frigjøringen av Finnmark markeres ved en tilstelning i Kirkenes", og at det fra norsk side burde være «en viss offisiell representasjon». ${ }^{42}$ Likevel mente UD at spørsmålet om omfang og deltakelse i arrangementet burde være «begrenset til det som finnes påkrevet». ${ }^{43}$

Det ble lange diskusjoner innad på norsk side om hvem som skulle representere den norske regjeringen, selv om det tidlig var klart at det heller ikke denne gangen var aktuelt med noen statsråd. UD ønsket at sjefen for Sør-Varanger bataljon, eller Distriktskommando Finnmark skulle være øverste norske representant. Mens diskusjonen om representasjon pågikk, begynte den sovjetiske siden å bli utålmodig. Den

\footnotetext{
${ }^{39}$ Notat, 28.10.1964, UD/Doss 8.6.15B/III.

${ }^{40}$ UD til Fylkesmannen i Finnmark, 12.11.1964, UD/Doss 8.6.15B/III.

${ }^{41}$ Notat, 31.3.1969, UD/Doss 8.6.15B/III.

${ }^{42}$ Notat, 31.3.1969, UD/Doss 8.6.15B/III.

${ }^{43}$ Notat, 31.3.1969, UD/Doss 8.6.15B/III.
} 
sovjetiske ambassadøren Sergej Romanovskij ga beskjed om at han «ville være nødt til å rapportere hjem at man øyensynlig på norsk side stilte seg negativt [til en felles markering i Kirkenes] hvis han ikke snart fikk opplysninger om regjeringens holdning til spørsmålet». ${ }^{44}$ Saken ble sendt til statsministerens kontor, og den 22 . mai ble det bestemt at fylkesmannen i Finnmark også denne gangen skulle være øverste sivile representant for Norge. ${ }^{45}$ Fra sovjetisk side ble det uttrykt skuffelse siden man «hadde tenkt seg representasjon på høyere nivå» enn de tidligere markeringene. ${ }^{46}$

Sovjetunionen hadde i april ytret ønske om flåtebesøk og utveksling av delegasjoner som del av markeringen. UD avslo flåtebesøket, og mente at en delegasjonsutveksling ikke kunne finne sted i forbindelse med markeringen. ${ }^{47}$ To dager senere skrev Aftenposten at Norge stilte seg "delvis avvisende til Sovjet-forslag» om markeringen i Kirkenes ${ }^{48}$ Aftenposten hevdet at man fra norsk regjeringshold "er lite lystne på å lage noe stort jubileum sammen med russerne nu så kort tid efter at SovjetSamveldet gikk i spissen for invasjonen i og okkupasjonen av Tsjekkoslovakia». ${ }^{49}$ Til slutt hevdet Aftenposten at det fra norsk side var «gitt klar beskjed om at hverken generaler eller statsråder vil stille til noen høytidelighet ved side med russerne i Kirkenes, og den norske representasjon vil bli ivaretatt av fylkesmannen i Finnmark og sjefen for Finnmark landforsvar». ${ }^{50}$

Aftenpostens oppslag vakte frustrasjon i UD, som ikke ønsket å framstå som blankt avvisende overfor sovjetiske myndigheter. ${ }^{51}$ Departementet «beklaget artikkelen som inneholdt både forvrengninger og direkte feilaktige opplysninger» til den sovjetiske ambassaden. ${ }^{52}$ For å korrigere inntrykket av at UD var avvisende til en felles markering, sendte UD ut en pressemelding der det ble understreket at arrangementet ville følge de samme linjer som forrige gang, og at regjeringen ville bli «representert ved fylkesmannen i Finnmark og en høyere offiser».$^{53}$ At det ikke skulle komme statsråder til markeringen, og at arrangementet ikke ville inneholde verken sovjetisk marinebesøk eller delegasjonsutveksling, ble dermed naturliggiort. Den sovjetiske ambassadøren var ifølge UD «tilfreds med forklaringen» han hadde fått fra departementet. ${ }^{54}$ Samtidig fortsatte sovjetiske myndigheter å presse på for å høyne den offisielle representasjonen under minnemarkeringen. Så sent som i begynnelsen av september fremmet den sovjetiske ambassaden forslag om at den sovjetiske visestatsministeren skulle

\footnotetext{
${ }^{44}$ Notat, 14.5.1969, UD/Doss 8.6.15B/III.

${ }^{45}$ SMK til UD, 23.5.1969, UD/Doss 8.6.15B/III.

${ }^{46}$ Notat, 30.5.1969, UD/Doss 8.6.15B/III.

${ }^{47}$ Notat, 7.7.1969, UD/Doss 8.6.15B/IV.

${ }^{48}$ Faksimile av Aftenpostens morgennummer 9.7.1969, UD/Doss 8.6.15B/IV.

${ }^{49}$ Faksimile av Aftenpostens morgennummer 9.7.1969, UD/Doss 8.6.15B/IV.

${ }^{50}$ Faksimile av Aftenpostens morgennummer 9.7.1969, UD/Doss 8.6.15B/IV.

${ }^{51}$ Moskva til UD, 11.7.1969, UD/Doss 8.6.15B/IV.

${ }^{52}$ Notat, 9.7.1969, UD/Doss 8.6.15B/IV.

${ }^{53}$ Pressemelding, 9.7.1969, UD/Doss 8.6.15B/IV.

${ }^{54}$ Notat, 9.7.1969, UD/Doss 8.6.15B/IV.
} 
delta, og ønsket at en norsk minister også skulle være til stede. UD avslo forespørselen, men kommenterte at ambassadøren «var skuffet over at man ikke kunne benytte den anledningen som her ville by seg til å styrke forbindelsene». .55

Markeringen i oktober 1969 foregikk i tråd med tidligere års seremonier, til tross for den turbulente opptakten (Aftenposten, 1969a, 1969b). Fra den norske ambassaden i Moskva ble det rapportert om at de sovjetiske avisenes dekning av markeringen var «velvillige og uten utfall mot norsk politikk». ${ }^{56}$

\section{4-1984: En sterkere norsk agenda}

I etterkant av 25-årsmarkeringen tok man fra norsk side et fastere grep om seremoniene i Kirkenes. I november 1969 skrev den norske ambassaden i Moskva til Utenriksdepartementet at vi i Norge burde «innstille oss på å markere oktober-jubileer ganske regelmessig. Det er her en god mulighet til å skape og utnytte en naturlig goodwill hos våre naboer og det vil da etter hvert være mulig å få det hele i faste former». ${ }^{57}$ Departementet var enig, men av andre grunner. I en egen rapport om 25-årsmarkeringen ble det stilt spørsmål om jubileene i Kirkenes bar preg av å være "en ensidig hyllest til Sovjetunionen». ${ }^{58}$ UD mente at det i så fall hadde sammenheng med at initiativet hver gang kom fra sovjetisk side, og at Sovjetunionen «på en måte «dyttet» feiringen på oss. Ved neste korsvei bør man fra norsk side ta et initiativ i god tid på forhånd og søke å få feiringen preget også av den innsats som ble giort fra alliert og norsk side». ${ }^{59}$

1970-tallet var preget av avspenning mellom supermaktene, med en første konferanse om samarbeid og sikkerhet i Europa og de første rustningsavtalene. Det kan se ut som norske myndigheter gjennom tiåret utarbeidet en tydeligere agenda for markeringene i Kirkenes. Første del av 1980-tallet representerte en ny nedkjøling mellom øst og vest og også dårligere vilkår for norsk-sovjetiske relasjoner. Til tross for de storpolitiske konjunkturene, fulgte markeringene i 1974 og 1984 den nå etablerte malen, med et norsk vertskap bestående av hærsjef eller en statssekretær fra Justis- eller Forsvarsdepartementet, høyt rangerte militære, samt regionale og lokale representanter som fylkesmannen i Finnmark og borgermester i Kirkenes. Disse tok imot en invitert sovjetisk delegasjon med tilsvarende representasjon. Ved 35-årsmarkeringen i 1979 ble det gjennomført en markering med kun regional representasjon, også dette i tråd med den etablerte tradisjonen (Aftenposten, 1979a, 1979b, 1979c; Pravda, 1979). Den sentrale hendelsen under alle markeringene var taler

\footnotetext{
${ }^{55}$ Notat, 4.9.1969, UD/Doss 8.6.15B/IV.

${ }^{56}$ Moskva til UD, 31.10.1969, UD/Doss 8.6.15B/IV.

${ }^{57}$ Moskva til UD, 4.11.1969, UD/Doss 8.6.15B/IV.

${ }^{58}$ Notat, 18.11.1969, UD/Doss 8.6.15B/IV.

${ }^{59}$ Notat, 18.11.1969, UD/Doss 8.6.15B/IV. Understreking i originalen. Utsagnet reflekterer for øvrig at Utenriksdepartementet nå utvetydig oppfattet Norsk-sovjetrussisk samband som representant for Sovjetunionen.
} 
og kranse-nedleggelser ved Frigjøringsmonumentet. Narrativet som ble formidlet gjennom markeringene holdt seg også stabilt; fra norsk side uttrykte man takknemlighet overfor de sovjetiske soldatene, og begge sider framhevet det gode og historisk fredelige naboskapet mellom statene og vennskapet og den giensidige respekten mellom det norske og det sovjetiske folket. Dette måtte bevares og utvikles i framtiden, het det i både norske og sovjetiske taler. (Aftenposten, 1974a, 1974b, 1974c, 1984; Kostikov, 1984; Kuznetsov, 1974; Udgaard, 1974).

Samtidig kom det gjennom andre halvdel av 1970-tallet i økende grad kritikk av norske myndigheters sikkerhetspolitikk i sovjetisk presse (Kan, 1988, s. 69-77). Ved 35-årsmarkeringen for frigjøringen i 1979 ble oppslagene om seremoniene i Kirkenes fulgt av skarpe utfall mot det norske Nato-medlemskapet. Mens veteraner og tidsvitner fra frigjøringen ble sitert på det varme vennskapet og den gjensidige respekten som oppsto mellom det norske og sovjetiske folk i 1944, pekte den sovjetiske pressen samtidig på hvordan Norge var under hardt press vestfra til å opptre som oppstillingsområde for Nato-styrker. Nato-medlemskapet var ifølge Izvestija et hinder for utvikling av tettere forbindelser mellom Norge og Sovjetunionen. Avisa viste til en angivelig voksende Nato-motstand i den norske opinionen og understreket hvordan medlemskapet splittet den norske opinionen og førte til intens politisk debatt i Norge og til og med demonstrasjoner (Aftenposten, 1979a; Golosjubov, 1979). Denne understrekingen av en angivelig splittelse i den norske befolkningen ble videreført i sovjetisk presse inn i de første årene av 1980-tallet.

\section{4: Nye relasjoner, samme naboskapsfortelling}

Med oppløsningen av Sovjetunionen og den kalde krigens slutt, ble høyspenning og blokkpolitikk byttet ut med lavspenning og raskt voksende kontakt over det som nå var blitt den norsk-russiske grensen i nord. Styrkeforholdet mellom den norske småstaten og den russiske naboen var også endret, og dette kom til uttrykk ved 50-årsjubileet for frigjøringen i 1994. Fra norsk side valgte man å utvide grunnrammene for feiringen $\mathrm{i}$ to tilsynelatende motstridende retninger. På den ene siden åpnet man for representasjon på høyeste politiske nivå, og imøtekom slik det som gjennom den kalde krigen hadde vært et gjentakende ønske fra sovjetisk side. På den andre siden la man frigjøringsmarkeringen inn i en klarere norsk nasjonal ramme, som strakte seg fra oktober 1994 til mai 1995 som en samlet markering av hele perioden fra frigjøringen av de første områdene i nord til avslutningen av krigen i mai 1945 (Aftenposten, 1994a, 1994b). Initiativet til markeringen kom nå fra nordnorske aktører, Sør-Varanger kommune og Finnmark fylkeskommune. ${ }^{60}$ Den lokale arrangementskomiteen var tydelig preget av den sterke optimismen som rådet etter jernteppets fall og etableringen av Barentsregionen som et rammeverk for økt samkvem på tvers av statsgrensene i nord. Komiteen så for seg «deltagelse på politisk

${ }^{60}$ Finnmark fylkeskommune til UD, 8.2.1994, UD/Doss 8.6.15B/Bd. VIII 1990-1994. 
toppnivå fra Norge og Russland», og hadde "et sterkt ønske om tilstedeværelse av den norske statsminister». ${ }^{61}$ Slik ble det også. For første gang deltok det norske kongeparet i frigjøringsmarkeringen i Kirkenes, sammen med Norges statsminister Gro Harlem Brundtland og utenriksministrene fra de to land. Den russiske utenriksminister Andrej Kozyrev deltok som president Jeltsins personlige representant. ${ }^{62}$

Dette var den mest storstilte markeringen så langt, både med tanke på representasjon, budsjett og omfang i tid. Den langstrakte markeringen ble rettferdiggjort av det runde tallet man feiret. Samtidig kan tidsrammen fra oktober til mai forstås som et uttrykk for at norske myndigheter ønsket å sette frigjøringsmarkeringene inn $\mathrm{i}$ en tydeligere norsk nasjonal kontekst.

Det sterkere norske grepet om markeringen endret ikke på narrativet som kom til uttrykk i symbolske handlinger og i taler, tvert imot; i den rådende Barentsatmosfæren ble det historisk gode og fredelige naboskapet hyllet, og visjonene for framtidig samarbeid ble formulert tydeligere og mer konkret enn før, særlig fra norsk side. Ved tunnelinngangen i Bjørnevatn holdt Kong Harald en tale der han takket Den røde arme og berømmet deres innsats i Norge. Soldatenes eksemplariske framferd viste at nazistenes skremsler om hva sovjettroppene ville bringe med seg var ubegrunnet, uttalte kongen. Rundt to tusen tilhørere hadde møtt fram (Verdens Gang, 1994). Izvestija gjenga deler av talen til ordfører i Sør-Varanger Alfon Jerijärvi, som framhevet sovjetsoldatenes hjelpsomhet: «Dere delte deres beskjedne soldatrasjoner med fremmede mennesker", sa Jerijärvi, som talte direkte til 50 sovjetiske veteraner som deltok i markeringen i Kirkenes på første benk sammen med 63 norske tidsvitner (Dragnes, 1994; Plutnik, 1995). Aftenposten trykket et stort oppslag med de sovjetiske veteranene, som hadde kommet reisende med buss over grensen fra en minneseremoni ved Litsa-fronten. I den nye atmosfæren kunne en pensjonert generaloberst fra russisk side spøke med at nå som jernteppet var borte, burde man bruke jernet til å bygge toglinje fra Nikel til Kirkenes (Dragnes, 1994).

\section{Frigjøringsmarkeringene som naboskapspolitikk}

Frigjøringsmarkeringene i Kirkenes har utgiort et kontinuerlig element i forholdet mellom Norge og Sovjetunionen/Russland gjennom den kalde krigen og inn i den postsovjetiske tida. Gjennom 2000-tallet har markeringene vokst og fått et sterkere preg av det mellomfolkelige samarbeidet som har grodd fram innenfor rammene av Barentsregionen. Samtidig har markeringene fătt større politisk betydning, som møtepunkt for de to landenes utenriksministre. Ved 70-årsmarkeringen i 2014 og igjen ved 75-årsmarkeringen i 2019 framsto arrangementet både som et politisk toppmøte og som en folkefest med bredt engasjement fra lokalsamfunnene på norsk og russisk side av grensen - til tross for høy bølgegang i det norsk-russiske forholdet

${ }^{61}$ Referat, 4.2.1994, UD/Doss 8.6.15B/Bd. VIII 1990-1994.

${ }^{62}$ Moskva til UD, 22.6.1994, UD/Doss 8.6.15B/Bd. VIII 1990-1994. 
for øvrig. At markeringene har blitt gjennomført i faste intervaller, også i perioder med høy sikkerhetspolitisk spenning, indikerer at de har spilt en rolle i å ivareta de bilaterale relasjonene. Det er ingenting i materialet vi har gjennomgått som tyder på at norske myndigheter noen gang vurderte å $i k k e$ markere frigjøringen, verken da initiativet først ble tatt i 1954, under turbulensen i 1969 eller i "Tsjernenko-årets» kjølige klima i 1984.

Samtidig viser materialet at kontinuiteten i minnemarkeringene ble etablert i en dragkamp mellom norske og sovjetiske aktører. Denne dragkampen handlet om hvordan frigiøringen skulle omtales og hvilket innhold de felles markeringene i Kirkenes skulle ha. Som vi har sett, var særlig de to første tiårene karakterisert av initiativ og ønskemål fra Sovjetunionen og Norsk-sovjetrussisk samband, som ble skalert ned av norske myndigheter - samtidig som man fra norsk side valgte å gå inn i vertskapsrollen og arrangere frigjøringsmarkeringer for inviterte sovjetiske gjester. Kildene viser paradoksalt nok at til tross for at det var den sovjetiske siden som var pådriver fra starten, var det norske myndigheter som fra 1964 påberopte seg en tradisjon i møte med sovjetiske ønskemål, som et diplomatisk spiselig argument for å holde frigjøringsmarkeringene innenfor de grunnrammene som den norske siden var komfortable med. Sovjetiske forsøk på å legge inn nye elementer i markeringene, som flåtebesøk, ble først motvillig akseptert og senere kontant avvist fra norsk side med begrunnelse i en allerede eksisterende tradisjon for markeringene. Ønsker fra sovjetisk side om å øke markeringenes betydning gjennom høyere politisk representasjon ble gjentatte ganger avvist fra norsk side, også dette ved å henvise til tradisjonen. Fra 1970-tallet tok norske myndigheter et sterkere grep om markeringene, og de påfølgende arrangementene til og med 1984 ble organisert etter de grunnrammene som det norske vertskapet hadde lagt.

Innenfor disse grunnrammene finner vi et sett med symbolske handlinger og et narrativ som har blitt gjentatt over tid; en norsk invitasjon til felles markering og en sovjetisk velvillig mottakelse, politisk representasjon på statssekretærnivå og kransenedleggelser ved Frigjøringsmonumentet. I norske taler finner vi takknemlighet overfor de sovjetiske soldatene, samt respekt og beundring for den selvoppofrende framferden sovjettroppene utviste på norsk jord. Dette har blitt ledsaget av formuleringer om historisk fredelige relasjoner og ønsker om et godt naboskap og samarbeid i framtida. Fra sovjetisk side har man tatt imot takksigelsene, understreket at sovjettroppene kom som befriere, talt om vennskap mellom det norske og sovjetiske folket og gjengjeldt formuleringene om framtidshåp for naboskapet. Da 50-årsmarkeringen for frigjøringen skulle markeres i 1994, valgte norske myndigheter å skalere arrangementet kraftig opp. Det er naturlig å se disse endringene i lys av både den rådende "Barentsbegeistringen» og det runde tallet som skulle markeres. Samtidig ble retorikken om godt naboskap gjentatt i Kirkenes i 1994 som tidligere år, og framtidsdimensjonen i denne fortellingen framsto nå som mer aktuell enn noen gang før. 
Sett i ettertid framstår frigjøringsmarkeringene som et sett av giensidige og gradvis permanentiserte symbolske handlinger og retorikk - med andre ord, en tradisjon. Som del av denne tradisjonen har frigiøringen i oktober 1944 blitt vevet inn $i$ et felles norsk-russisk narrativ om godt naboskap. Dette narrativet - som ble gjentatt i seremoniene i Kirkenes gjennom hele perioden som behandles her - strekker seg fra fortida (historisk fredelige relasjoner), via frigjøringen i 1944 og inn i framtida (gjensidige ønsker om å utvikle samarbeid). I seremoniene har man brukt elementer fra fortida for å fremme og naturliggiøre en konstruktiv tone i de samtidige og framtidige bilaterale relasjonene. Narrativet har understreket stabiliteten i det norsk-russiske forholdet - samtidig som markeringene og talemåtene har virket nettopp i retning av å skape stabilitet.

Materialet som ligger til grunn for vår artikkel viser samtidig at dette naboskaps-narrativet var basert på det man kan kalle for et minste felles multiplum av henholdsvis norsk og sovjetisk forståelse av hva frigjøringen var, hva den betød for de bilaterale relasjonene og hva man gjensidig ønsket seg for framtida. Materialet viser tydelig hvilke emner man ikke ønsket som del av en slik omforent fortelling, og hvordan ulike emner ble forsøkt forhandlet inn. Norsk UD var i 1954 på vakt mot forsøk på å forstørre den sovjetiske innsatsen, og holdt fast ved at frigjøringen omfattet Øst-Finnmark, ikke Nord-Norge eller hele Norge, slik den sovjetiske ambassaden, avisa Friheten og den sovjetiske pressen i noen tilfeller formulerte det. Den sovjetiske understrekingen av at Den røde arme kom som befriere hadde ved den første markeringen allerede tydelig fotfeste giennom norsk begrepsbruk fra $1945 \mathrm{og}$ oppføringen av Frigjøringsmonumentet - men likevel valgte UD i sitt kommuniké i 1954 den mer nøytrale formuleringen om at sovjettroppene «rykket inn» i Finnmark. Et gjennomgående trekk fra norsk side gjennom den kalde krigen er at man ønsket å skrive inn norsk innsats under frigiøringen i narrativet. På 1950- og 1960-tallet var man i tillegg særlig opptatt av å unngå anti-tysk retorikk fra sovjetisk side. Den imøtekommende norske naboskapsretorikken fra statssekretæren som ledet det norske vertskapet i 1959, framstår som en bevisst strategi for å legge lokk på anti-tyske utsagn fra sovjetisk side. Sovjetisk kritikk av det norske Nato-medlemskapet ble ikke fremmet direkte av sovjetiske delegasjonsmedlemmer i taler i Kirkenes, men kom opp i sovjetisk presse i forbindelse med markeringene.

Dette siste viser kanskje tydeligst hvordan det omforente narrativet om godt naboskap var basert på et minste felles multiplum. Det viser også at narrativet ikke alltid var framtredende eller tilstede når det bilaterale forholdet ble omtalt utenfor Kirkenes. Samtidig indikerer kontinuiteten i narrativet fra den første markeringen i 1954 fram til 50-årsjubileet i 1994 at tradisjonen fikk en egen tyngde over tid. Gjennom minnemarkeringene ble en forestilling om godt naboskap talt og handlet fram, og den regelmessige og giensidige bekreftelsen av dette kan forstås som en egen kraft i det bilaterale forholdet. Slik har minnemarkeringene i Kirkenes, til tross for dragkamp, fungert som en konstruktiv møteplass for å utvikle og kultivere en tradisjon som har virket $\mathrm{i}$ retning av å dempe konfliktnivå og spenninger. At 


\author{
minnemarkeringene har vokst i omfang og politisk representasjon under det som \\ omtales som en ny kald krig fra 2014, viser oss at de muligens har større betydning \\ for naboskapet i dag enn noen gang før.
}

\title{
Litteratur
}

Aagedal, O., Botvar, P. K. \& Brottveit, Å. (red.). (2017). Kunsten å jubilere: Grunnlovsfeiring og minnepolitikk. Pax forlag.

Aftenposten. (1954a, 13. september). Sovjet-delegasjon til Kirkenes: Til feiringen av 10-årsdagen for NordNorges frigjøring.

Aftenposten. (1954b, 16. oktober). Sovjet-russerne på visittrunde: Programmet for minnehøytideligheten i Finnmark fastlagt.

Aftenposten. (1954c, 18. oktober). Mottagelse i Sovjet-ambassaden.

Aftenposten. (1954d, 25. oktober). Det norske folk glemmer ikke sovjet-soldatenes tapre innsats.

Aftenposten. (1954e, 26. oktober). Minnesten over russiske falne i Tromsø.

Aftenposten. (1954f, 27. oktober). Minnehøytideligheten i Kirkenes.

Aftenposten. (1964, 26. oktober). Tyve-årsminnet for Finnmarks frigjøring.

Aftenposten. (1969a, 23. oktober). 25-årsminnet for frigjøringen av Finnmark feires.

Aftenposten. (1969b, 24. oktober). Frigjøringen i 1944 av Øst-Finnmark feires.

Aftenposten. (1974a, 17. oktober). Sovjet minner om sin frigjøring av Finnmark i 1944.

Aftenposten. (1974b, 24. oktober). Frigjøringen av Øst-Finnmark.

Aftenposten. (1974c, 26. oktober). Gjensyn med 30 år gamle minner.

Aftenposten. (1979a, 26. oktober). Øst-Finnmarks frigjøring minnet.

Aftenposten. (1979b, 29. oktober). Øst-Finnmark: 35 år siden frigjøringen.

Aftenposten. (1979c, 30. oktober). Frigjøringen minnes.

Aftenposten. (1984, 24. oktober). Frigjøring markeres.

Aftenposten. (1994a, 24. mars.). Jeltsin vil til Norge i oktober.

Aftenposten. (1994b, 6. september). Frigjøringsjubileet starter i oktober.

Aune, A. (1996). Kongens mann i nord. Aschehoug forlag.

Bones, S. (2015). Krig, frigjøring og minne. Kampen mot Nazi-Tyskland i norsk-sovjetiske relasjoner. I F. Fagertun (red.), Krig og frigjøring i nord (s. 143-152). Orkana Akademisk.

Bones, S. \& Mankova P. (red.). (2010). Norway and Russia in the Arctic. UiT Norges arktiske universitet.

Büchten, D., Jackson, T. N. \& Nielsen, J. P. (red.). (2004). Norge - Russland: Naboer gjennom 1000 år. Scandinavian Academic Press.

Dolmatovskij, Je. (1959). U nasjikh severnykh sosedej. Pesjkom v Norvegiju. Literaturnaja gazeta, 144.

Dragnes, K. (1994, 24. oktober). Glede og sorg i frigjøringsfeiring. Aftenposten.

Egge, Å., Holtsmark, S. G. \& Komarov, A. A. (red.). (2015). Aleksandra Kollontaj: Diplomatiske nedtegnelser 1922-1930. Res Publica.

Eriksen, A. (1999). Historie, minne og myte. Pax forlag.

Eriksen, A. (1995). Det var noe annet under krigen: 2. verdenskrig i norsk kollektivtradisjon. Pax forlag.

Finnmarken. (1959, 27. oktober). Vinterkulde over minnehøytiden.

Gamnes, O. B. (2014). 70 let v mire u granitsy 1944-2014: Sbornik rasskazov sovremennikov i otsjevidtsev. Dagfinn Hansens Trykkeri AS.

Golosjubov, Ju. (1959, 25. oktober). Norvegija blagodarit vas. K 15-letiju osvobozjdenija Sovjetskoj Armijej Severnoj Norvegii. Izvestija.

Golosjubov, Ju. (1979, 24. oktober). Tot pamjatnyj god. Izvestija.

Gorter, A. A., Gorter, W. T. \& Suprun, M. N. (2005). Frigjøringen av Øst-Finnmark 1944-45. Arkhangelsk Pomor Forlag.

Holtsmark, S. G. (red.). (1995). Norge og Sovjetunionen 1917-1955: En utenrikspolitisk dokumentasjon. J. W. Cappelens forlag AS.

Holtsmark, S. G. (red.). (2015a). Naboer i frykt og forventning: Norge og Russland 1917-2014. Pax forlag.

Holtsmark, S. G. (2015b). Om Den røde hær rykker inn i Norge ... Spørsmålet om sovjetisk deltakelse i frigjøringen av Norge 1941-1944. I F. Fagertun (red.), Krig og frigjøring i nord (s. 11-24). Orkana Akademisk.

Holtsmark, S. G., Komarov, A. A. \& Prozumensjtsjikov, M. Ju. (red.). (2020). Sovjetunionens kommunistiske parti og Norge 1952-1967: En dokumentasjon. Orkana Akademisk. 
Izvestija. (1954a, 24. oktober). Desjatiletie osvobozjdenija Sovjetskoj Armijej Severnoj Norvegii.

Izvestija. (1954b, 26. oktober). Norvezjskij narod otmetsjaet 10-letie osvobozjdenija Severnoj Norvegii Sovjetskoj Armijej.

Jackson, T. N. \& Nielsen, J. P. (red.). (2005). Russia - Norway: Physical and symbolic borders. Languages of Slavonic Culture.

Kan, A. (1988). Naboskap under kald krig og perestrojka: Forholdet Norge-Sovjet sett fra Moskva. Institutt for forsvarsstudier.

Komarov, A. A. (2015). Sovjetisk-norske forbindelser og frigjøringen av Øst-Finnmark i 1944. I F. Fagertun (red.), Krig og frigjøring $i$ nord (s. 61-71). Orkana Akademisk.

Kostikov, M. (1984, 24. oktober). Nezabyvajemaja stranitsa. Pravda.

Kuznetsov, Ju. (1974, 24. oktober). Zjivaja pamjat Norvegii. Pravda.

Lippe, J. (1964). Finnmark fritt! Erindringer fra frigjøringskampene mot Hitler-armeen i nord. Ny Dag.

Markussen, J. Aa. (2020). Krigshistoriens livsløp: Samspillet, konkurransene og kampene om iscenesettelsen av NordNorges krigshistorie. [Doktorgradsavhandling]. UiT Norges arktiske universitet.

Markwick, R. (2012). The great patriotic war in Soviet and post-Soviet collective memory. I D. Stone (red.), The Oxford handbook of postwar European history (s. 692-713). Oxford University Press.

Meretskov, K. (1964, 26. oktober). Pamjatnye dni. Pravda.

Myklebost, K. A. \& Bones, S. (red.). (2012). Caution \& compliance: Norwegian-Russian diplomatic relations 1814-2014. Orkana Akademisk.

Myklebost, K. A., Nielsen, J. P. \& Rogatchevski, A. (red.). (2020). The Russian revolutions of 1917: The Northern impact and beyond. Academic Studies Press.

Narinskiy, M. (2015). Minnet om andre verdenskrig i Russland. I F. Fagertun (red.), Krig og frigjøring $i$ nord (s. 131-142). Orkana Akademisk.

Nielsen, J. P. (2001). Tsar-Russland: Potensiell trussel eller god nabo? Et gjensyn med 'den russiske fare'. I F. Fagertun, J. E. Myhre \& T. Ryymin (red.), Det farefulle nord: Trusler og trusseloppfatninger knyttet til Nord-Norge gjennom tusen år (s. 67-90). Universitetet i Tromsø

Nielsen, J. P. (red.). (2014). Russland kommer ncermere: Norge og Russland 1814-1917. Pax forlag.

Nordlys. (1954, 25. oktober). Verdig feiring.

Plutnik, A. (1995, 24. januar). Bremja sosedstvo s Rossijej. Izvestija.

Pravda. (1954, 25. oktober). Norvezjskij narod otmetsjaet desjatiletie osvobozjdenija Severnoj Norvegii Sovjetskoj Armijej.

Pravda. (1964, 26. oktober). Torzjestva v Kirkenese.

Pravda. (1979, 31. oktober). Torzjestva v Kirkenese.

Rotihaug, I. (2000). 'For fred og vennskap mellom folkene'. Sambandet Norge-Sovjetunionen 1945-1970. Forsvarsstudier $1 / 2000$.

Sjtsjerbakov, V. (1964, 26. oktober). Druzjba, skreplennaja na fiordakh. Izvestija.

Udgaard, N. M. (1974, 26. oktober). Positiv Sovjet-omtale av Finnmark-jubileet. Aftenposten.

Vavilov, V. (1964). K 20-letiju osvobozjdenija Severnoj Norvegii sovjetskimi vojskami. V kraju polunotsjogo solntsa. Literaturnaja gazeta, 128.

Verdens Gang. (1954, 28. oktober). Sovjet-kunstnere i Aulaen søndag.

Verdens Gang. (1964a, 23. oktober). Vil russerne lette på jernteppet ved Pasvik?

Verdens Gang. (1964b, 26. oktober). Frigjøringen av Kirkenes feiret.

Verdens Gang. (1994, 25. oktober). Varm feiring i polarnatten.

Wijermars, M. (2019). Memory politics in contemporary Russia: Television, cinema and the state. Routledge. 